\title{
The Research on The Evolution of Asia-pacific Regional Economic Integration and Countermeasures
}

\author{
Min Chen ${ }^{1}$ \\ ${ }^{1}$ Economics and Management School, South East University, PRC, Financial and Economic School, Chongqing Three Gorges University, \\ PRC
}

\begin{abstract}
The Asia-pacific region is the area with vast development accompanied by subtle evolution worldwide under frequently changeable global economic circumstance. The development of regional trade agreements (RTAs) in this area is most complicated and comprehensive. The interactive influence of economic growth and trade liberalization, and of the combination and differentiation, has grandly contributed the development of RTAs in the process of regional integration in this area, which has formed the strong driving force of the regional economic integration. On the basis of characteristics of the evolution in the course of Asia-pacific regional economic integration, this paper has analyzed the driving mechanism of the integration evolution and future development direction, then put forward some corresponding countermeasures.
\end{abstract}

\section{INTRODUCTION}

The Asia-pacific region covers the countries along the entire Pacific rim in broad sense. While in narrow sense, it mainly refers the APEC members countries in east Asia, south east Asia, as well as those countries located in the west bank of Pacific Ocean. In recent years, since Doha round negotiation under WTO is at a deadlock, the bilateral and multilateral regional trade agreements (RTA) are emerged significantly. It seems that the global economic center is transferred to the Asia-pacific region gradually, which becomes the most dynamic, potential and influential area in the world. Due to the complicated geopolitical situation in this region, as well as the diversified economic level and social mechanism, there are many problems to be settled in the course of the regional economic integration, from the functional integration to system integration

In the course of historical integration evolution in this area, the two theme regional cooperation spirits, i.e., the opening regionalism and competitive liberalization, are widely applied as a guiding ideology in this area. The diversified regional cooperation is developed further and creatively while the competition become fierce more and more simultaneously. Both trade frictions and cooperation have contributed to a boom in inter-regional and transregional trade agreements, out of a pursuit for common sustainable economic interests. Under the "noodle bowl" pattern, two clear paths to Asia-pacific free trade area construction are presented, which are Regional Comprehensive Economic Partnership (RCEP) directed by Association of South-east Asia Nations (ASEAN) and Trans-pacific Strategic Partnership (TPP) once directed by the United States Previously. Both RTAs, participated by many Asia-pacific countries, are considered as diversified, trans-regional and inclusive free trade agreement leading to Asia-Pacific Free Trade Area(FTAAP).Therefor, the ongoing uncertain opposites, compatibility and unification arising from these two main RTAs will influence the trend and direction of the economic integration in this region. With the application of China’s “The Belt \& Road Initiative” in 2013, probably it will become "the third path" to FTAAP with its profound influence on the Asian countries.

\section{LITERRATURE}

Nowadays, the contents of FTA (Free Trade Agreement) is covered by the liberalization regarding the trade in goods, service and technology. In the Asia-Pacific region, the establishment of free trade Area can not only avoid the adverse effects of the "spaghetti bowl" effect effectively to some extent, but also improve trade levels by the formation of a unified trade policy in the region. As to the free trade agreements that China has signed or is negotiating, China is more inclined to establish FTAs with the target countries mainly distributed in the Asia-Pacific region, especially the ones in the East Asia and South Asia area. In recent years, based on the development model of East Asia and Latin America in several perspectives, some scholars ( Quan Y, 2010; Kim, 2013 ) have conducted comparison study in these two areas to explore the development model and path of the Asia-Pacific region. They believe that the Asia-Pacific Free Trade Area is a natural choice for regional economic integration which can satisfy the economic interests of all 
members. Sheng B (2014), Tang GQ \& Wang ZY ( 2014 ) found the Asia-Pacific Free Trade Area (FTAAP) is a strategic path to regional economic integration and a higher degree of free trade.

With the continuous development of the free trade areas, some scholars have focus on their study of the "wheel and axle-spoke" theory applied to the FTA in terms of the incentives, the possible trend and the real influence on trade, welfare and industrial output. The early study conducted by a large number of scholars mostly is focused on constructing theoretical models to probe into the influence of the "wheel and spoke" structure on the economic policy, industrial layout, trade and welfare effects of the FTA, most of them believe that FTA is mutual beneficial to the economy and trade development for both the wheel and axle countries. Puga D \& Venables A J (1995) have analyzed the economy and trade effect of the member states of FTA by the DixitStiglitz model. They found that the wheel countries would have some special location advantages from the establishment of FTA, which would generate more economic benefits for the wheel country deriving from the gathering of a large number of enterprises. Through comparative research, Wonnacott R. J \& Wonnacott, P (1995) found that wheel countries would benefit special economic interests in investment and trade at least.

Using (Global Trade Analysis Project) GTAP model, Chong (2007) also found that it is the wheel countries instead the spoke countries can obtain more economic benefits after the establishment of FTA. Baldwin R E (2009) also pointed out that the wheel and spoke structure has a certain negative impact on the economic development of spoke countries. He also put forward some strategies that how the small economies in the East Asian region avoid becoming spoke countries while developing trade with large economies. Furthermore, Seidmann (2009) have studied the trade transfer effects between different free trade areas, and believe that the internal FTA will generate trade transfer effects in a certain period of time through a balanced path. Kawabata (2015) analyzed the formation mechanism of FTA in vertical markets with the application of the Cournot competition model. After the study on the tariff and welfare effects of the "wheel and spoke" structure of FTA, he believed that the construction of FTA can form an internal balance mechanism. Both the wheel and spoke countries can benefit from it.

Through the existing literature analysis, we find the scholars have conducted a lot of researches on the trade effect on FTA, and on the economic integration in AsiaPacific area. However, as to the integration evolution and the path to FTAAP, as well as the trade effect in this region, still need to be discussed and explained further, especially in the simulating and predicting the macroeconomic effects and the industrial changes.First, confirm that you have the correct template for your paper size. This template has been tailored for output on the USletter paper size. If you are using A4-sized paper, please close this file and download the file for "MSW_A4_format".

\section{CHARACTERISTICS OF ASIA-PACIFIC REGIONAL ECONOMIC INTEGRATION}

\subsection{Lack of official mechanism of APEC as an economic forum}

With the rapid progress of region-wide trade and investment cooperation, Asia-pacific Economic Cooperation (APEC) emerged as a product of further regional economic cooperation and development. It was initiated in 1989 by the former Australian Prime Minister Hawke, who perceived the threat of the rapid pace of European Community's moving towards its common market, and the potentials of dynamic growth patterns of newly industrializing countries of Asia and the emerging market in China. With a view to boost economic cooperation and development within the Asia-Pacific region as well as to the world, APEC developed rapidly in terms of institutional development, membership and coverage of issues. in 1997, the member countries in APEC has grown to 21, and four main committees and 11 working groups in operation are constructed to hold forums for communication frequently. With the attendance of China, Hongkong, Mexico, Taiwan, Papua Guinea, Chile, Peru, Russia, etc., member economies combined is approximately $57 \%$ of total world income, and $46 \%$ of global trade volume. Though APEC is of fast development, it is still of the characteristic of non-official economic forum. Therefore, some relative representative trade and investment liberalization goals, the Bogo goal, Individual Action Plan (IAP) and Early Voluntary Sectoral Liberalization (EVSL), are difficult to realize because of the lack of the construction of official organization.

\subsection{Uneven national strength and dominated by strong economys}

Though the total income and trade volume of APEC account for half of the world total, even a higher interregional trade percentage, the economic level and size among these nations are most complex which vary from one to another significantly, not only including some most developed economies like United States, Canada, Japan, Australia, but also some less-developed countries ranking at the bottom of 100 , as well as some newly emerging economies, for instance, Korea, Singapore, etc.. Hence, the wide-region RTAs and FTAs in this region, represented by US and ASEAN as developed and lessdeveloped economy respectively, also reflected the conflicts and integration between the north and the south, as well as their different interest resorts.

For most developing economies, the industries of which are usually at the lower end, and their strong economic and technology interdependence on the developed countries make them not in a position to set trade rules and regulations, and it seems unequal to the undeveloped countries most times because of the uneven profit distribution. Take the wide-region TPP directed by US for example, though the RTA includes many 
developing countries, the higher standards concerning environmental protection, labor, intellectual property rights, government procurement, etc., are all tailor-made for the interests of the developed countries

\subsection{Further regional economic cooperation accompanied by deeper fragmentation}

The Asia-pacific region is the most active area of world trade and investment, also is the most diversified and overlapped area in terms of wide-range RTAs. Most economies are different members in different RTAs with different trade rules and standards. Therefore, the possible realization of FTAAP in this region, either through path of TPP or way of RCEP, will not be a simplified unification of all RTAs. Hence there is a long way to go to keep a balance of interests and development of all parties, to bridge the system fragmentation, and to close the standards and rules differentiation.

\section{THE TYPICAL PERIODIC STAGES OF INTEGRATION IN ASIA-PACIFIC REGION}

Owing to the economy diversity and complexity in this region, as well as the sensitivity of some geopolitical factors, the regional economic integration in this area is comparatively complicated and difficult. Based on the demands of different interests, the imbalance of economic development and inequality of cooperation, rapidly spreading wave of regionalism, and under loose and non-official framework of APEC, the member countries' attitude towards the construction of the FTAAP is consistently changed in compliance with the subtle international political and economic environment. The regional economic integration faces many uncertainties and complexities to solve. The table1a has revealed the number of RTAs the leading economies signed in this region, in which the dynamic change has reflected the copetition relationships in the regional economic integration.

TABLE 1. The NUMBER OF RTAs SIGNED IN THE ASIA-PACIFIC REgION(DEADLINE OCTOBER, 2019)

\begin{tabular}{|c|c|c|c|c|c|c|c|c|}
\hline \multirow[t]{2}{*}{ economy } & \multirow[t]{2}{*}{$\begin{array}{l}1971- \\
1988\end{array}$} & \multirow[t]{2}{*}{$\begin{array}{l}1989- \\
1997\end{array}$} & \multirow[t]{2}{*}{$\begin{array}{l}\text { 1998- } \\
2008\end{array}$} & \multirow[t]{2}{*}{$\begin{array}{l}2009- \\
2019\end{array}$} & \multicolumn{2}{|c|}{ signed RTAs } & \multicolumn{2}{|c|}{$\begin{array}{ll}\text { RTAs } & \text { under } \\
\text { negotiation }\end{array}$} \\
\hline & & & & & total & $\begin{array}{l}\text { Inter- } \\
\text { region } \\
\text { RTA }\end{array}$ & total & $\begin{array}{l}\text { Inter- } \\
\text { region } \\
\text { RTA }\end{array}$ \\
\hline Australia & 3 & 0 & 4 & 2 & 9 & 9 & 5 & 4 \\
\hline Canada & 0 & 3 & 4 & 2 & 9 & 5 & 11 & 9 \\
\hline Japan & 0 & 0 & 10 & 3 & 13 & 11 & 6 & 4 \\
\hline United States & 1 & 1 & 12 & 0 & 14 & 8 & 2 & 1 \\
\hline $\begin{array}{l}\text { New } \\
\text { Zealand }\end{array}$ & 2 & 0 & 4 & 4 & 10 & 10 & 2 & 2 \\
\hline Singapore & 1 & 1 & 17 & 2 & 21 & 15 & 4 & 2 \\
\hline Brunei & 0 & 1 & 6 & 1 & 8 & 7 & 1 & 1 \\
\hline Chile & 3 & 1 & 18 & 2 & 24 & 16 & 1 & 1 \\
\hline China & 1 & 0 & 8 & 3 & 12 & 10 & 13 & 6 \\
\hline $\begin{array}{l}\text { Hongkong, } \\
\text { China }\end{array}$ & 0 & 0 & 1 & 2 & 3 & 2 & 0 & 0 \\
\hline Taibei & 0 & 0 & 4 & 2 & 6 & 6 & 2 & 2 \\
\hline Philippine & 2 & 1 & 5 & 1 & 9 & 6 & 1 & 1 \\
\hline Korea & 3 & 0 & 6 & 4 & 13 & 7 & 6 & 6 \\
\hline Malaysia & 1 & 1 & 7 & 4 & 13 & 10 & 2 & 2 \\
\hline Mexico & 3 & 2 & 6 & 5 & 16 & 9 & 2 & 2 \\
\hline Malaysia & 0 & 2 & 5 & 1 & 8 & 6 & 1 & 0 \\
\hline Russia & 0 & 13 & 2 & 0 & 15 & 0 & 2 & 1 \\
\hline $\begin{array}{ll}\text { Papua } & \text { New } \\
\text { Guinea } & \end{array}$ & 2 & 1 & 1 & 1 & 5 & 3 & 0 & 0 \\
\hline Peru & 0 & 4 & 4 & 8 & 16 & 10 & 1 & 1 \\
\hline Thailand & 1 & 2 & 7 & 1 & 11 & 8 & 3 & 1 \\
\hline Vietnam & 1 & 1 & 5 & 1 & 8 & 6 & 3 & 1 \\
\hline
\end{tabular}

Note: Inter-region RTA refers to the asia-pacific region broadly not only members under the framework of APEC Source of data: WTO home $>$ Trade Topics $>$ Regional Trade Agreements $>$ RTAs database 


\subsection{Commencing and accelerating Stage of integration (1989-1997)}

Before the establishment of APEC, though a large number of RTAs was reached in this region, most of them are based upon unilateral generalized preferential trade agreement (GSTP), which is granted by the developed countries to developing countries. Therefore, it is prominently different between the RTAs before and after 1989.

Directed by the policy of multilateral and regional cooperation dominated by The United States, APEC was established in 1989, and since then it has experienced nearly a decade of rapid development. The members increased from the original 12 associations, including six countries of ASEAN, the United States, Canada, Japan, Australia, New Zealand and South Korea in 1989, to 21 members in 1997, and remain unchanged so far. In 1993, a most prominent meeting from national leader level instead of ministerial level is regarded unofficially the initial of the summit which then be hold every year. Then in 1994, APEC put forward the "Bogor goals" in Indonesia conference, ie., to achieve the long-term goal of trade and investment liberalization and facilitation by developed members and developing members in 2010 and 2020 respectively. With the further concrete principles and contents of the Bogor goals, three pillars of APEC are formed, namely, content covering trade and investment liberalization and facilitation, as well as economic and technical cooperation.

In 1996, APEC put forward "Marla Action Plan", and proposed the collective action plan for the Bogor goals, as well as member countries' unilateral action plan (IAP) to achieve further commitment. With a package of goals and proposals promoted, APEC become an influential regional non-official cooperation organization in the Asiapacific region, and the centripetal force among APEC members is greatly improved.

\subsection{Fragmenting stage of integration}

The Asia-pacific region is the most dynamic economic development region in the world, is also the region with most uneven regional economic development, and with the most complicated regional geopolitical relations among the member countries. Though several sets of integration goals are proposed, it seems extremely difficult to realize free trade, thus the FTAAP failed to make substantive progress. Because of the APEC approach emphasizes being flexible, progressive and open, so diverges and conflicts seems to be inevitable in the process of integration, which are arising from nonbinding principles under APEC and constraint mechanism of RTA, and the hastened liberalization pattern in western countries and gradual liberalization in East Asian countries, as well as developed economies' radical liberalization concept and east Asia countries' gradual opening perception. A $\mathrm{s}$ a matter of fact, most east Asian countries are not in a position to accept excessive investment and trade liberalization, which results in a sluggish development in the way to the FTAAP.
Furthermore, the outbreak of the Asian financial crisis in 1998 deteriorated the east Asia nations' FTAAP concept, and they started seeking inner cooperation by themselves. Differentiation became more serious when the Doha round negotiation at the beginning of the 21st century is blocked. Accompanied by the weakened APEC function, and prosperously emerged global RTAs, many APEC members started to construct their own network of RTAs actively, hence a substantial RTAs sprung up in the Asia-pacific region. Lacking necessary coordinating and directing mechanism, the fragmentation phenomenon of regional economic cooperation will be more serious, and the overlapped and wide-region RTAs towards FTAAP will exist for a long time.

Place figures and tables at the top and bottom of columns. Avoid placing them in the middle of columns. Large figures and tables may span across both columns. Figure captions should be below the figures; table heads should appear above the tables. Insert figures and tables after they are cited in the text. Use the abbreviation "Fig. 1 ”, even at the beginning of a sentence.

\subsection{Re-accelerating stage of integration}

Experienced the above differentiation stage, the Asiapacific regional economic integration enter into another accelerating consolidation stage again. As early as when APEC put forward the Bogor goal, developing APEC as an official mechanism and building FTAAP are widely discussed unofficially. When the APEC business advisory council bring them up in 2004, the United States and other countries support strongly, but most of the east Asian countries keep a conservative attitude owing to their weak economic strength and the improper economic and export structure. Without efficient function of APEC, a large number of bilateral and multilateral RTAs are signed in the Asia-pacific region, which composed the diversified and complicated pattern of noodle bowl. Followed by the fragmenting stage, another stage of reaccelerating integration is produced with the changing economic situation. The outbreak of international financial crisis and the European debt crisis, and the emergence of some new market countries as a new engine of global economic growth in this region, the US choose to go back to and dominate Asia-pacific market through trans-pacific partnership ( TPP), in view of sharing the demographic dividend in Asia and avoiding being marginalized in Asian markets. Though the Trump government has exit TPP in January, 2017, as a result of prioritized "U.S. interests" policy, which has emphasized aggressively pursuing bilateral agreements and regionalized cooperation instead multilateral trade, TPP has still influenced Asia-Pacific area significantly.

In fact, TPP is one of the main RTAs in Asia-pacific region established in 2005 by Brunei, Australia, Singapore, New Zealand. Aiming at strengthening the multilateral trading system development in this region, the United States declared participating TPP and become a leading country in 2008, thus P12 was formed (member countries including Australia, Brunei, Chile, the United States, Malaysia, New Zealand, Peru, Singapore, 
Vietnam, Mexico, Japan and Canada to negotiate their further economic cooperation. The main negotiation issues mainly are related to a higher standards and rules in the fields of agriculture, labor, environment, government procurement, investment, intellectual property protection, trade in services, and standard of origin, safeguard measures, technical trade barriers, sanitary measures, transparency, etc.. And in October 2015, P12 reached the agreement and formed formally directed by US. To some extent, US's declaration of withdrawal from TPP in 2017 has eased the tense regional economic situation in this area, but the challenges and threaten from the rapid growth of TPP to another big regional cooperation organizations (ASEAN) was seriously damaged, even facing being splitting. In fact, Four of ten ASEAN members are also included In TPP, which are Singapore, Malaysia, Brunei, Vietnam. In a view of re-balancing the swept influence of the United States on the Asia-pacific region, Regional Comprehensive Economic Partnership (RCEP) was put on the schedule by ASEAN and other countries.

Based on the existing RTAs and the framework for the "10+N" (RCEP) negotiations, the ASEAN initiate a package of negotiations from November 2012, and also has made substantive progress. The members contains 10 ASEAN countries, China, Japan, South Korea, India, Australia and New Zealand. Therefore, the two clear paths to FTAAP through two giant RTAs are presented. In short, the overall uncertainties in both TPP and RCEP, and the unity of Asia-pacific economic integration is still unprecedented.

\section{DRIVING FORCE IN THE PROCESS OF INTEGRATION EVOLUTION}

\subsection{Mutual influence of economic growth and trade liberalization}

The increasing economic cooperation and the improving degree of integration in this region, is as a result of the mutual influence of economic growth and trade liberalization. As an important pattern, APEC model is regarded as a significant organization to stimulate the region's economic cooperation and growth, as well as to realize FTAAP. That is, the establishment of APEC embodies the new features of open regionalism of inclusiveness, equality and progressive, while FTAAP is regarded as the deepening and extension of trade liberalization and competition.

Promoting regional economic growth and pursing maximum mutual benefits while exploring trade openness, is the important issue for all APEC countries. While one country's attitude towards regional trade liberalization and integration is differ, according to the economic growth is increased stable or not. Usually an continuous rapid economic growth will result in a deeper trade liberalization, otherwise, a slowing down trade openness.

Interacted by the driving from the economic growth and the deepening of trade liberalization, the trade barriers are reduced or removed consistently, and the regional economic integration is promoted through zigzagged evolution. Some new issues in line with the changing situation have been incorporated into the cooperation framework, including building a global supply chain connected, participating in the global production chain by small and medium-sized enterprises, and implementing effective and non-discriminatory policy, as well as some new market-oriented innovation policy.

\subsection{Deep penetration from the economic field into the non-economic field}

The massive development trend of the economic integration in the Asia-pacific region, boost the further development of the Asia-pacific regional economic integration, as well as the possible construction of reciprocally profitable FTAAP. To achieve a higher liberalization than that of WTO, we should not only adhere to the spirit of the Bogo goal in 2004, emphasizing the facilitation and liberalization of trade and service trade, but also some other non-economic contents, involving financial cooperation security, anticorruption cooperation, cooperation against terrorism, environmental protection, public health security cooperation, etc.. These cooperation in the fields of economic and non-economic between government and non-government, partly eliminate the unsustainable factors in the process of economic growth and integration.

\section{CONCLUSIONS AND COUNTERMEASURES}

From the above, it's obviously that the development of RTAs is most complicated and comprehensive in AsiaPacific area, in which different RTAs with checks and balances will coexist in a certain long period. Simultaneously, the Emerging of substantial sustainable development policies combined with the rising of some newly-emerging economies will influence the regional economic integration in this region, as well as the trend of the possible path to FTAAP. Some proposals are put forward as follows.

\subsection{To seek mutual benefit balance among RTAs To bring trade standards in line with international new ones}

Most economics are active in signing wide-region RTAs in this region. The number of RTAs they have signed are noticeably increased in recent years. With a view to achieve comprehensive and strategic development, all countries should keep a subtle benefit balance with the RTA partners in the changing situation, especially the countries are both as a member of TPP and potential member of RCEP. As we all know that TPP is a China exclusive trade agreement while RCEP is an America exclusive one. With the two giant RTAs' long term 
checks and balance, the attitude of the member countries will even influence the possible trend to FTAAP.

\subsection{To bring trade standards in line with international new ones}

With the establishment of comprehensive and high level RTA, a package of trade policies and higher trade standards will be applied, which will bring great changes in this region. Their gradually adjusted trade standards and rules will make the Asia-pacific regional economic integration move forward greatly, also will make China, the most important developing country in the world, accept and improve their trade standards in accordance with the developed countries with higher standard application.

With the construction of free trade areas in this region, all countries should take their geographical and economic advantages, enhance the radiating and driving ability in Asia-pacific area. For many emerging and influential economies, it is a good opportunity to upgrade and speed up the development of related industries, enhance the level of economic and trade cooperation with Asiapacific countries and regions, to further stimulate local economic potential and improve their standards covering environment, labor, health etc.

\subsection{To boost the partial unification of different RTAs}

Base on equality and mutual benefits, all countries may expand their existing RTAs and integrated into one. Though TPP have come to force already, the next important RTA, ie. RCEP, require these countries' joint efforts to bring it come into effective and to keep a balance in Asia-pacific area. Due to the complexity of political, economic and other sensitive issues, the unification of different RTAs is a tough task to fulfill though it is a general world trend nowadays. With the swept influence in this region, the development of individual RTA definitely will contribute a lot to the unification of trade rules, which is a realistic approach to the further regional cooperation and integration in this region.

\section{REFERENCES}

1. S. Kim,, I. Park, and S. Par, "A Free Trade Area of the Asia Pacific: Is It Desirable?”, Journal of East Asian Economic Integr ation, vol. 17( 1), pp.3 - 25, 2013.

2. D.Puga, and A J. Venables, "Preferential Trading Arrangements and industrial Location”, Journal of International Economics,vol.43(3- 4), pp.347-368, 1995.

3. R. J. Wonnacott, \& P.Wonnacott, “Liberalization in the Western Hemisphere: New Challenges in the Design of a Free Trade Agreement, North American Journal of Economics and Finance, vol. 6(2), pp.107119,1995.
4. J.Y. Lake "On the different geographic characteristics of Free Trade Agreements and Customs Unions”Departmental Working Papers, 2014.

5. P. Saggi, K. Missios, and H. M. Yildiz "External Trade Diversion, 'Exclusion Incentives and the Nature of Preferential Trade Agreements'”, Mpra Paper,vol. 99, pp.105-119, 2015.

6. Y . Kawabata, "Endogenous Formation of Free Trade Agreements in Vertically Related Markets”, Research in Economics,vol. 69( 2), pp.214 - 223, 2015. 